\title{
江戸会所地の土地所有に関する研究 \\ A STUDY ON THE LANDOWNERSHIP OF “KAISHOCHI”
}

\author{
李 佶 勲*
}

Kilhun LEE

\begin{abstract}
This study is to consider the process how "Kaishochi" (the open space in the block), which was planned in early Edo town, transformed into the housing lot, focusing on Nihonbashi area. To understand the landownership of "Kaishochi", two historical maps (Cadastre) are utilized for this analysis. This paper consists of two contents;(1)landlords and the property forms around "Kaishochi" in the eighteenth and the nineteenth century, (2) "Kokenkin"(land price) around "Kaishochi". The purposes of this paper are to clarify the aim of possessing "Kaishochi" and to consider the distribution of "Kaishochi" by "Kokenkin". Through the transition of "Kaishochi", particular land formation in Edo, the urban space of Edo town transformed through mutual adjustments amongst local community.
\end{abstract}

\section{Keywords ; Edotown,Kaishochi,Landownership,Landowner,Nihonbashi area,Kokenzu(Cadastre),Kokenkin(Land price)} 江戸、会所地、土地所有、地主、日本橋地域、沽券図、沽券金

\section{1. はじめに}

江戸の会所地はどのように変容していったのか。

玉井哲雄 ${ }^{1}$ 、本論の対象地域である日本橋北では享保期以降に会 所地が沽券地化したことを明らかにしている。本稿では、とりわけ 寛保 4 年（1744）と明治 6 年（1873）の沽券図を用いて会所地の沽 券地化を具体的に比較分析する。ここで、沽券地化というのは、拝 領地ないし町共用地として存在した明地である会所地が、売買が可 能な土地になることを表す。

本稿の分析は以下の二つからなる。すなわち、(1)十八世紀・十九 世紀における会所地とその周辺の地主および所有形態、(2)会所地と その周辺の沽券金に構成される。

本稿の対象地域は、会所地が江戸後期まで残っていた日本橋北で ある。注目する時期としては、江戸時代の寛保 4 年 (1744)、明治 6 年 $(1873)$ の、二つの時点で会所地の土地所有 ${ }^{2}$ 追跡していく。

江戸の会所地に関する先行研究はほとんどが江戸の町割りの説 明の一環としてふれるものが多い。ところが既存の研究では、史料 的制限も多いと思われるものの会所地の土地所有や、会所地に対す る沽券図の分析が欠けていることが指摘される。本稿では会所屋敷 を所有している地主が、他にどの屋敷を所有しているのかを調心゙る ことにより、会所屋敷を所有する目的を明らかにしたい。そして会 所屋敷とその周辺の沽券金で会所屋敷を改めて位置づけたい。

\section{2. 史料について}

会所地の沽券地化に関する史料はほとんどないが、現存する幾つ かの地図上でその所有形態の変遷を追うことができる。
当該地域の沽券絵図史料としてあげられるのは、「佃島沽券絵図」 (宝永 7 年)、「寛保沽券図 4 」(寛保 4 年)、「第壱大区沽券図 ${ }^{5} 」($ 明治 6 年、以下、明治沽券図と表記) の三つがある。この内、会所地の土地 所有関係が確認できる「宽保沽券図」・明治沽券図」二つの史料を用 いて、土地所有について、共時的・通時的な観点から考察する。こ れにより、江戸の後期、明治初期の二つの時点での会所地の特徵を 読み取る。

\section{3. 会所地とその周辺の地主}

\section{3-1-1 十八世紀、「寛保沽券図」から見る会所地}

\section{会所屋敷の地主}

会所屋敷の地主とはどのような人々であったのだろうか。「寛保沽券 図」には延享期（1744-1748）における会所屋敷の地主が記されている。

「寛保沽券図」とは、江戸町奉行の命令により町名主がその支配地 域を数町単位で作製した絵図である。その記載内容は、街路に面し て両側に町屋敷が並んだ状態を描き、その個々の町屋敷の中に、町 屋敷の間口・奥行の寸法、地価である沽券金、地主名、そして町屋 敷の実際の管理者である家守の名を記したものである。現在の地籍 図と土地台帳を兼㸚たようなものと考えればよい。

では、ここから会所屋敷の地主に焦点を当てて詳細に調べてみよ う。対象地域のうち、「寛保沽券図」が残っていて会所屋敷の地主が わかる部分は図 1 である。図 1 にある 14 ケ所の会所地の地主を調べ た結果が表 1 である。会所屋敷は全部 52 ケ所で、そのうち、地主が 不明な 1 ケ所と地主名が読み取れない 4 ケ所を除くと、47 ケ所の会 所屋敷に対して分析ができる。 


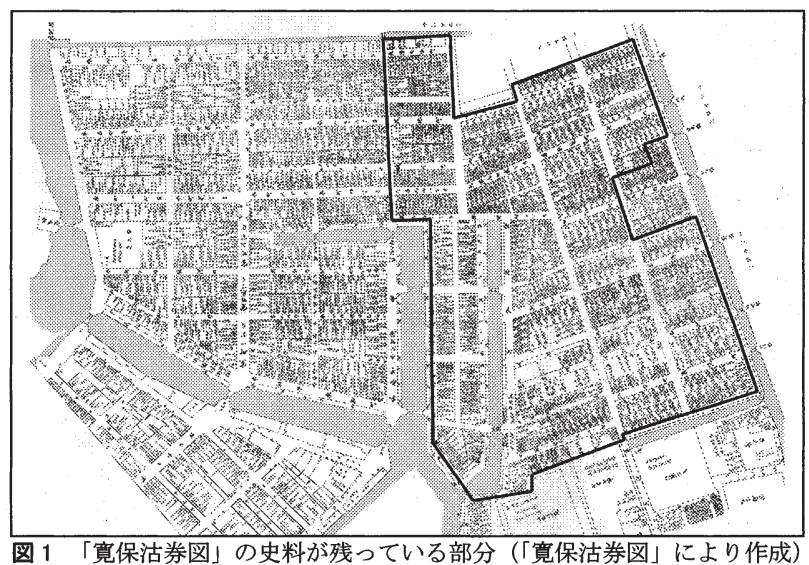

表 1 寛保期会所地の地主（「宽保沽券図」により作成）

\begin{tabular}{|c|c|c|c|}
\hline 町名 & 地番 & 地主名 & 所有形態 \\
\hline \multirow{2}{*}{ 大伝馬塩町 } & 01 の内 & 吉兵衛 & 隣接屋敷/町内屋敷/町外屋敷 \\
\hline & 16 & 四郎左衛門 & 隣接屋敷 \\
\hline \multirow{2}{*}{ 鉄砲町 } & 26 & 小林勘平 & 会所地のみ \\
\hline & 27 & 不明 & - \\
\hline \multirow{2}{*}{\multicolumn{2}{|c|}{$\begin{array}{r}28 \\
\text { 大伝馬町 1 丁目 } 29\end{array}$}} & 三郎右衛門 & 隣接屋敷/町外屋敷 \\
\hline & & よう & 町内屋敷/町外屋敷 \\
\hline & 30 & 町中 & 隣接屋敷/町外屋敷 \\
\hline \multirow{5}{*}{ 大伝馬町 2 丁目 } & 30 & 馬込勘解由 & 隣接屋敷/町外屋敷 \\
\hline & 31 & 太郎 & 会所地のみ \\
\hline & 32 & 口右衛門 & - \\
\hline & 33 & 長三郎 & 町外屋敷 \\
\hline & 34 & むめ & 会所地のみ \\
\hline \multirow{3}{*}{ 通油町 } & 24 & 通塩町勘兵衛 & 隣接屋敷/町内屋敷/町外屋敷 \\
\hline & 25 & 孫兵衛 & 会所地のみ \\
\hline & 26 & 佐久間町 1 丁目清兵衛 & 町内屋敷/町外屋敷 \\
\hline \multirow{6}{*}{ 通旅籠町 } & 17 の内 & 権兵衛 & 隣接屋敷/町外屋敷 \\
\hline & 18 の内 & 不明 & - \\
\hline & 23 & 藤左衛門 & 会所地のみ \\
\hline & 24 & 清助 & 会所地のみ \\
\hline & 25 & 延寿院 & 会所地のみ \\
\hline & 26 & 六左衛門 & 町外屋敷 \\
\hline \multirow{4}{*}{ 田所町 } & 21 & 小西吉左衛門 & 会所地のみ \\
\hline & 22 & 七兵衛 & 町内屋敷/町外屋敷 \\
\hline & 23 & 川口田又太夫 & 会所地のみ \\
\hline & 24 & 伊勢屋長兵衛 & 隣接屋敷/町内屋敷 \\
\hline 堀留町 3 丁目 & 01 & もよ & 隣接屋敷/町外屋敷 \\
\hline \multirow{2}{*}{ 新材木町 } & 19 & 嘉右衛門 & 会所地のみ \\
\hline & 20 & 弥治兵衛 & 会所地のみ \\
\hline \multirow[t]{2}{*}{ 岩代町 } & 01 & 町年寄 樽屋藤左衛門 & 会所地のみ \\
\hline & 24 & 海保半兵衛 & 隣接屋敷 \\
\hline \multirow[t]{2}{*}{ 長谷川町 } & 25 & 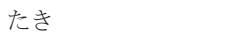 & 会所地のみ \\
\hline & 26 & とめ & 会所地のみ \\
\hline \multirow{4}{*}{ 富沢町 } & 25 & 長兵衛 & 町外屋敷 \\
\hline & 26 & 藤兵衛 & 町外屋敷 \\
\hline & 27 & 三郎兵衛 & 町外屋敷 \\
\hline & 28 & 伊右衛門 & 隣接屋敷/町外屋敷 \\
\hline 新臀町 & 04 & 伝左衛門 & 隣接屋敷/町内屋敷 \\
\hline \multirow[t]{13}{*}{ 芳町 } & 01 & 三左衛門 & 隣接屋敷/町外屋敷 \\
\hline & 02 & 六兵衛 & 隣接屋敷/町外屋敷 \\
\hline & 03 & 三左衛門 & 隣接屋敷/町外屋敷 \\
\hline & 04 & 高橋寿貞 & 会所地のみ \\
\hline & 05 & 土田友二郎 & 会所地のみ \\
\hline & 06 & 近藤 $\square \square$ & - \\
\hline & 07 & 広瀬春悦 & 会所地のみ \\
\hline & 08 & 田村吉益 & 会所地のみ \\
\hline & 09 & 田村吉益 & 会所地のみ \\
\hline & 10 & 山本宗 $\square$ & - \\
\hline & 11 & 広野貞佐 & 会所地のみ \\
\hline & 12 & 矢代善哲 & 会所地のみ \\
\hline & 13 & 次郎兵衛 & 隣接屋敷/町外屋敷 \\
\hline
\end{tabular}

\author{
14 次郎兵衛隣接屋敷/町外屋敷 \\ 15 い< \\ に準じて作成。 \\ 会所地のみ \\ 注地番は「明治沽券図」に隻じて \\ 一の表記は地主名が正確ではなく、判断できない場合。
}

町共用ないし拝領地であった会所地が沽券地化される際、その屋敷は 誰が所有したのか。表 2 は会所屋敷を所有している地主が他にどこの屋 敷を持っているかを調查した結果である。屋敷の持ち方は、会所屋敷の み所有する場合、会所屋敷のほかに隣接する屋敷も所有する場合、町外 にある屋敷も所有する場合、町外および町内にある屋敷の両方も所有す る場合の四つのパターンに分けられる。表 2 によると、47 ヶ所のうち、 隣接している屋敷の地主が所有している会所屋敷は 17 ヶ所 (36.17\%) を占めていることがわかる。また、会所屋敷のみ所有している場合は 22 ヶ所 $(46.81 \%)$ である。会所地の地主は、ほとんどが隣接している屋敷 の地主、あるいはそれまで周辺に土地などを所有してはいなかったが会 所地のみを購入し所有していた町人であることがいえる。

表 2 寛保期会所屋敷の所有形態（「寛保沽券図」および表 2 により作成） \begin{tabular}{lcccccc}
\hline 区分 & 会所屋敷のみ & 隣接屋敷* & 町外屋敷 & 町内・町外 & 合計 \\
\hline 寛保沽券図 & 22 & 17 & 5 & 3 & 47
\end{tabular} $\begin{array}{llllll}\text { (寛保 } 4 \text { 年) } \quad(46.81 \%) & (36.17 \%) & (10.64 \%) & (6.38 \%) & 47\end{array}$ 注 *隣接屋敷とは、隣接する屋敷の他、町外・町内にも屋敷を所有する場合、 隣接したものと見なす。つまり、隣接屋敷に書かれている数字は、表 1 に よる隣接/町内/町外、隣接/町内、隣接/町外の場合を全部含めた数である。

\section{会所地の地主と開発形態}

前項では、会所地の所有者について調べてみた。これからは表 2 を用いて、会所地の地主がどのような意図で会所地を所有していた のかについて考察してみよう。

最も多い場合である会所屋敷のみ所有する地主は、日本橋北の沽券 図以外の部分で土地を所有していた可能性があるものの、江戸商業地 の中心部であった日本橋北では土地を持っていなかった地主がこの 地域に新規参入したのは確かである。3-2でより深く考察するが、会 所屋敷の価值を判断するため、寛保期の会所屋敷の沽券高を調べてみ る。町によって異なるが、坪当たりの沽券高が町内の他の屋敷と比べ ると安いか、また同じくらいだということがわかる。以上のことから、 会所屋敷の夕所有している地主は、比較的に安い会所地を用いて商業 を中心地に参入しようとした人々だったことが推測できる。表 1 を見 ると通旅籠町、新材木町、岩代町、長谷川町、芳町に会所屋敷のみ 所有している土地が集中していることをわかる。会所屋敷なら表通 りに接していない裏地として、地理的によくない条件であったが、 それにもかかわらず日本橋北で商業を創めようとした町人が多かっ たことが推測できる。

表 2 によると隣接している屋敷の地主が会所屋敷を所有する場合は、 36. 17\%を占めている。これは筆者が研究開始当初に会所地の地主として 想定したもので、 $1 / 3$ に達することがわかる。地主の所有意図を調べるた め、大伝馬塩町を例としてあげながら会所屋敷の地主を確認すると、図 2のように会所地に隣接している地主が会所地を所有していることが わかる。会所地がゴミ置場に使われたのは『正宝事録』7で確認できる が、沽券地化した後、どのように使われたのかについては史料が残され ていない。『御府内沿革圖書』によると新道は延宝期（1673-1681 年） に通され、貞享元年（1684）に塞がれ、宝永元年（1704）に再び道にな $る^{8}$ 。新道が通ることによって間口が開けられた会所屋敷の出入りは新 道の廃止後、20 年間どのように行ったのかを考えると、会所屋敷は新 道が塞がれても隣接する敷地からアプローチが可能なところであった 
ことが考えられる。以上のことから、会所屋敷は店舗を拡張するため、 あるいは倉庫など、表通りに面する屋敷の付加的な機能を持つ建物や空 地で構成されたと推測できる。

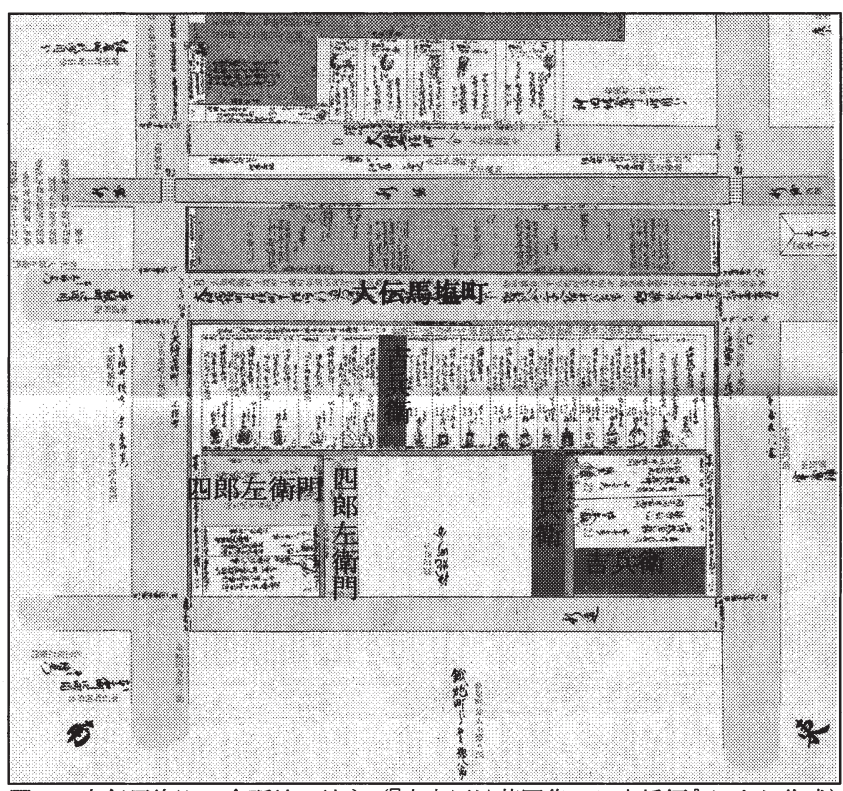

図 2 大伝馬塩町の会所地の地主 (『中央区沿革図集一日本橋編』により作成)

表 2 によると隣接してはいないが町内にある屋敷の地主が所有して いる場合が 10.64\%を占めている。この場合は、隣接している屋敷の地 主が所有している例と同様と見なすことができる。店舗の拡張のため、 町内の比較的安い会所屋敷を所有しようとしたことがわかる。

最後に町外にある屋敷の地主が会所屋敷を所有する場合で、不在地 主と家守の登場、土地所有という近代的な概念の発生という二つの 点から投資として土地経営をしょうとしたのではないかという予測が 立てられる。土地経営をした例として通油町を調べると、会所屋敷の地 主が通塩町勘兵衛·佐久間町 1 丁目清兵衛と書いてある。清兵衛の場合、 見世の本店は佐久間町 1 丁目にあって通油町にも土地を所有していた ことが分かる。清兵衛は通油町内にも土地を所有しているが見世の拡張 というよりは、佐久間町 1 丁目を拠点とし他の町でも土地経営をしてい たのではないかと考えられる。表 2 によと、町外屋敷の地主が会所屋 敷を所有している場合は五ヶ所で、二つは比較的に沽券金が高い大伝馬 2 丁目と通旅籠町で、投資の価值が高かったと思われる。その一方、三 つは比較的に沽券金が安かった富沢町に集中していることがわかる。

\section{3-1-2十九世紀、「明治沽券図」から見る会所地}

\section{会所屋敷の地主}

「明治沽券図」とは明治 6 年に発行された沽券図で、「寛保沽券図」 から 129 年後の日本橋の姿がよくわかる9

「明治沽券図」の記載内容は、地番、売買価格である沽券金、地主名、また 坪数である。明治 6 年に、個々の土地に現在のもとになる地番がつけられた のが大きな変化であるだろう。また「寛保沽券図」とは違って、地主名が名 字まで記されており、同じ地主が所有している土地をより正確に確定するこ とができる (表 3)。町の特徴としては、本銀町 1 丁目、本石町 1 丁目、本町 1 丁目、金吹町、本両替町について新道が通らず、正方形街区がそのまま残っ ていることが挙げられる。これらの町の会所屋敷は、地番がなく『 $\square$ の内』 と表記され、隣㢺している屋敷に所属していたことが特徴的である。

また会所屋敷とその周辺は同じ名字を持つ一家が所有していること が多い。例を挙げると、『松沢家』は本銀町 1 丁目、本石町 1 丁目、本
銀町 3 丁目、本石町 3 丁目、大伝馬町 2 丁目、弥生町にある会所屋敷の 一帯を所有している（表 3 ・図 3)。「寛保沽券図」に比べると、会所屋 敷が周辺の土地集積に重要な役割を果たしていることが伺える。特に 『松沢家』が所有している土地の内、その中心地に見える本銀町 3 丁目、 本石町 3 丁目の場合は、まるで会所屋敷を中心にして土地を所有してい るような形をしていることに気づく。『松沢家』当主である松沢孫八は 元禄期（1688-1704 年）に大坂より江戸に進出し、漢方薬の薬種問屋 であったが、後に油を披うようになり江戸最大の油問屋になった ${ }^{10}$ 。江 戸時代の本石町 3 丁目周辺の状況は確認できないが、松沢孫八は本石町 3 丁目に商業を創め、会所屋敷を含むその周辺まで、その勢力をどんど ん広げたと考えられる。

松沢孫八が本石町 3 丁目を拠点として勢力を拡張したと思われる一 方、下村家は、通旅籠町を拠点にしていることがわかる（図 4 ）。下 村彦右衛門正啓は寛保 3 年に通旅籠町 ${ }^{11}$ で木綿問屋である「大丸屋」 を開店する。これが現在の大手企業である「大丸」の基となったのだ が、その勢力の証といえるのが、通旅籠町の南側の裏通りが「大丸新 道」と呼ばれていたことであろう ${ }^{12}$ 。この下村家が拠点である通旅籠 町のほとんどの会所屋敷を占めていることに気づくだろう。

新道が廃止され、また再び復活した後、倉庫あるいは空地だった会 所屋敷とその前にある新道が段々と商業地として活性化する理由の 一つとして挙げられるのが、大店の会所屋敷の占有だったと考えられ る。大店の占有にしたがって、裏町であった会所屋敷とその前の新道 は賑やかになったのである。「明治沽券図」によると、大店がほとん どの会所地を所有していることをわかる（表 3）。

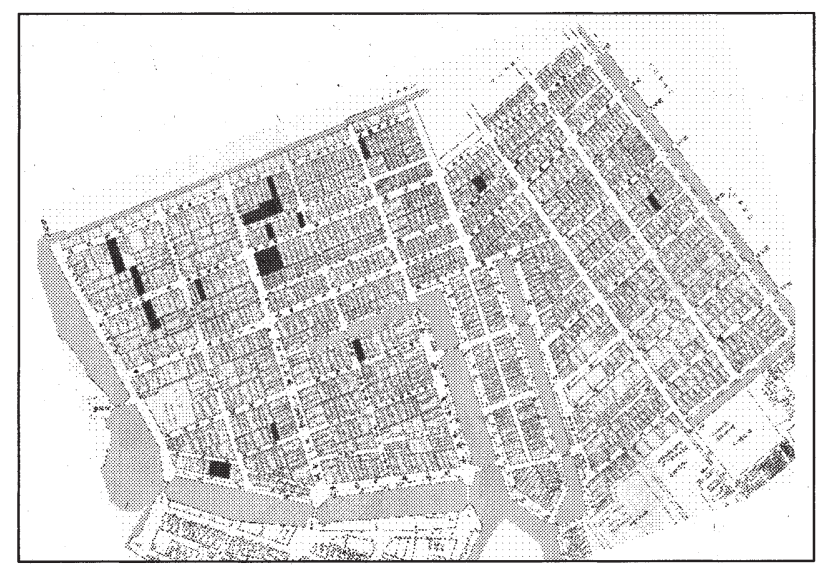

図3『松沢家』が所有していた土地 (「明治沽券図」により作成)

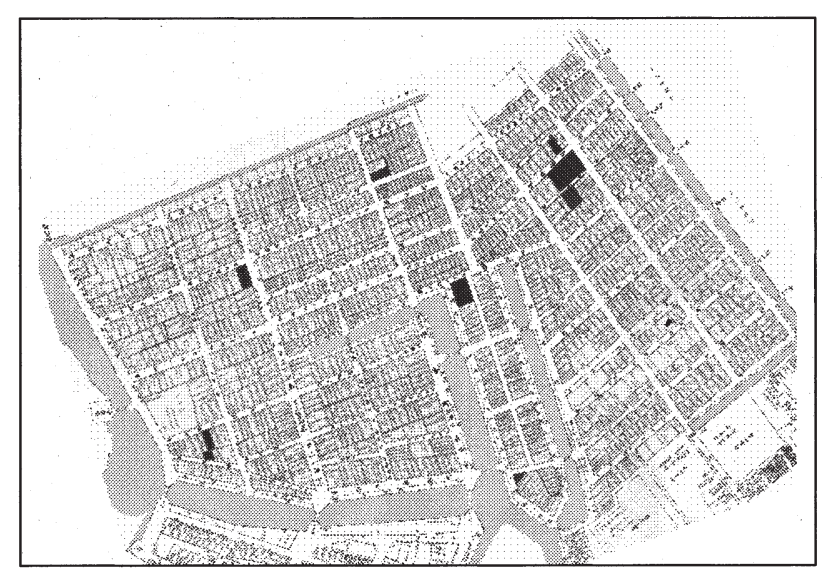

図4『下村家』が所有していた土地（「明治沽券図」により作成） 
表 3 明治 6 年会所地の地主（「明治沽券図」により作成）

\begin{tabular}{|c|c|c|c|}
\hline 町名 & 地番 & 地主 & 所有形態 \\
\hline \multirow{5}{*}{ 本銀町 1 丁目 } & 06 の内 & 中井新左門 & 隣接屋敷 \\
\hline & 08 の内 & 松沢孫八 & 隣接屋敷/町外屋敷 \\
\hline & 09 の内 & 田中キミ & 隣接屋敷 ～～～～～～～～ \\
\hline & $14 の$ の & 斉藤安兵衛 & 隣接屋敷/町外屋敷 \\
\hline & 15 の内 & 乾九兵衛 & 隣接屋敷/町外屋敷 \\
\hline 本銀町 2 丁目 & 13 & 大鐘長太郎 & 会所地のみ \\
\hline \multirow{8}{*}{ 本石町 1 丁目 } & 08 の内 & 松沢孫八 & 隣接屋敷/町外屋敷 \\
\hline & 13 の内 & 田中松之助 & 隣接屋敷/町内屋敷/町外屋敷 \\
\hline & 17 の内 & 橋本清右衛門 & 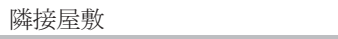 \\
\hline & 18 の内 & 松沢久吉 & 隣接屋敷/町外屋敷 \\
\hline & 19 の内 & 後藤長左衛門 & 隣接屋敷/町外屋敷 \\
\hline & 20 の内 & 坂口吉左衛門 & 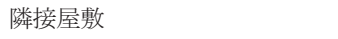 \\
\hline & 21 の内 & 倉永蔵 ～～～～～～～～ & 隣接屋敷 ～～～～～～～～ \\
\hline & 26 の内 & 村越庄左衛門 & 隣接屋敷/町外屋敷 \\
\hline \multirow{2}{*}{ 本石町 2 丁目 } & 18 & 門池和助 & 隣接屋敷 \\
\hline & 19 & 金沢三右衛門 & 町内屋敷 \\
\hline \multirow{4}{*}{ 本石町 3 丁目 } & 21 & 松沢孫八 & 隣接屋敷/町内屋敷/町外屋敷 \\
\hline & 22 & 松沢幾三郎 & 会所地のみ \\
\hline & 23 & 松沢幾三郎 & 会所地のみ \\
\hline & 24 & 松沢孫八 & 隣接屋敷/町内屋敷/町外屋敷 \\
\hline \multirow{9}{*}{ 本石町 4 丁目 } & 15 & 小津清左衛門 & 隣接屋敷/町内屋敷/町外屋敷 \\
\hline & 16 & 長谷部喜右衛 & 町外屋敷 \\
\hline & 17 & 藤田常太郎 & 会所地のみ \\
\hline & 18 & 相原孫左衛門 & 会所地のみ \\
\hline & 30 & 太田吉左衛門 & 町外屋敷 \\
\hline & 31 & 生川ユミ & 会所地のみ \\
\hline & 32 & 三井次郎右衛 & 町外屋敷 \\
\hline & 33 & 不明 ～～～～～～～～～～ & - \\
\hline & 34 & 石川ヨシ & 会所地のみ \\
\hline \multirow{2}{*}{ 本町 1 丁目 } & 13 の内 & 水島三之助 & 隣接屋敷 \\
\hline & 17 & 小野里力三郎 & 会所地のみ \\
\hline \multirow{2}{*}{ 本町 2 丁目 } & 19 & 山路茂兵衛 & 隣接屋敷 \\
\hline & 20 & 田中三四郎 & 隣接屋敷（他会所地 1 筆） \\
\hline \multirow{2}{*}{ 金吹町 } & 04 の内 & 中井新右門 & 隣接屋敷/町外屋敷 \\
\hline & 06 & 中井新右門 & 隣接屋敷/町外屋敷 \\
\hline \multirow{2}{*}{ 本石町十軒店 } & 08 & 亀谷常七 & 会所地のみ \\
\hline & 09 & 樋口林八 & 会所地のみ \\
\hline \multirow{5}{*}{ 岩附町 } & 07 & 下田万七 & 会所地のみ \\
\hline & 08 & 益田又左衛門 & 会所地のみ \\
\hline & 09 & 不明 & - \\
\hline & 10 & 不明 & - \\
\hline & 11 & 不明 & - \\
\hline \multirow{2}{*}{ 大伝馬塩町 } & 01 & 秋田太吉 & 隣接屋敷 \\
\hline & 16 & 室井喜代三郎 & 町外屋敷 \\
\hline \multirow{2}{*}{ 鉄砲町 } & 26 & 小林勘平 & 会所地のみ \\
\hline & 27 & 小林勘平 & 会所地のみ \\
\hline \multirow{3}{*}{ 大伝馬町 1 丁目 } & 28 & 西村三郎右衛 & 隣接屋敷/町内屋敷/町外屋敷 \\
\hline & 29 & 田中三四郎 & 町外屋敷（他会所地 1 筆） \\
\hline & 30 & 久須木七左衛 & 町内屋敷/町外屋敷 \\
\hline & 30 & 小暮安右衛門 & 町外屋敷 \\
\hline & 31 & 松沢台次郎 & 会所地のみ \\
\hline 大伝馬町 2 丁目 & 32 & 松沢台次郎 & 会所地のみ \\
\hline & 33 & 坂江吉右衛門 & 町外屋敷 \\
\hline & 34 & 綿貫清兵衛 & 隣接屋敷 \\
\hline & 24 & 川尻彦兵衛 & 町外屋敷 \\
\hline 通油町 & 25 & 川尻彦兵衛 & 町外屋敷 \\
\hline & 26 & 坂江吉右衛 & 町内屋敷/町外屋敷 \\
\hline & 17 の内 & 大貫博右衛門 & 隣接屋敷 \\
\hline & 18 の内 & 葉原七兵衛 & 隣接屋敷/町内屋敷/町外屋敷 \\
\hline 通旅筑管町町 & 23 & 下村源蔵 & 町内屋敷（向う側）/町外屋敷 \\
\hline 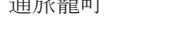 & 24 & 下村源蔵 & 町内屋敷（向う側）/町外屋敷 \\
\hline & 25 & 下村正太郎 & 町内屋敷（向う側） \\
\hline & 26 & 林留右衛門 & 町内屋敷（向う側）/町外屋敷 \\
\hline 本両替町 & 13 の内 & 細井保 & 会所地のみ \\
\hline 本革屋町 & 06 & 樽俊之助 & 隣接屋敷 \\
\hline 駿河町 & 14 & 三井八郎右衛 & 隣接屋敷/町外屋敷 \\
\hline 室町 3 丁目 & 20 & 竹原久右衛門 & 隣接屋敷/町外屋敷 \\
\hline
\end{tabular}

\begin{tabular}{|c|c|c|c|}
\hline \multirow{3}{*}{ 品川町裏河岸 } & 08 & 南平左衛門 & 会所地のみ \\
\hline & 09 & 岡田平馬 & 会所地のみ \\
\hline & 10 & 岡田平馬 & 会所地のみ \\
\hline \multirow{4}{*}{ 長浜町 } & 01 & 田村善次郎 & 会所地のみ \\
\hline & 02 & 中村九兵衛 & 会所地のみ \\
\hline & 03 & 長島庄兵衛 & 会所地のみ \\
\hline & 04 & 宇田松三郎 & 会所地のみ \\
\hline 堀留町 2 丁目 & 22 & 杉森稲荷 & 会所地のみ \\
\hline \multirow{4}{*}{ 田所町 } & 21 & 小倉慶之助 & 会所地のみ \\
\hline & 22 & 東六郎 & 会所地のみ \\
\hline & 23 & 川喜多ユリ & 会所地のみ \\
\hline & 24 & 饗庭又兵衛 & 町外屋敷 \\
\hline \multirow{2}{*}{ 元浜町 } & 16 & 伊達浅之助 & 隣接屋敷/町外屋敷 \\
\hline & 17 & 栗谷利兵衛 & 会所地のみ \\
\hline \multirow{2}{*}{ 弥生町 } & 04 & 長島三郎兵衛 & 会所地のみ \\
\hline & 05 & 松沢ロク & 町外屋敷 \\
\hline 堀留町 3 丁目 & 01 の内 & 勝本庄兵衛 & 隣接屋敷 \\
\hline \multirow{2}{*}{ 新材木町 } & 19 & 伊東伊之助 & 会所地のみ \\
\hline & 20 & 清水金七 & 会所地のみ \\
\hline 岩代町 & 01 & 関左七 & 会所地のみ \\
\hline \multirow{3}{*}{ 長谷川町 } & 24 & 建石三蔵 & 隣接屋敷/町内屋敷 \\
\hline & 25 & 小栗兆兵衛 & 会所地のみ \\
\hline & 26 & 村越庄左衛門 & 隣接屋敷/町内屋敷/町外屋敷 \\
\hline \multirow{4}{*}{ 富沢町 } & 25 & 安井治兵衛 & 会所地のみ \\
\hline & 26 & 三橋半次郎 & 会所地のみ \\
\hline & 27 & 鈴木治右衛門 & 町外屋敷 \\
\hline & 28 & 奥田小三郎 & 隣接屋敷/町内屋敷 \\
\hline \multirow[t]{8}{*}{ 新臀町 } & 04 & 鹿島チョ & 隣接屋敷/町内屋敷/町外屋敷 \\
\hline & 01 & 竹原久右衛門 & 隣接屋敷/町外屋敷 \\
\hline & 02 & 星野新七 & 会所地のみ \\
\hline & 03 & 竹原久右衛門 & 隣接屋敷/町外屋敷 \\
\hline & 04 & 高橋利冶 & 会所地のみ \\
\hline & 05 & 会議所附 & 町内屋敷/町外屋敷 \\
\hline & 06 & 古市傅兵衛 & 町内屋敷（向う側） \\
\hline & 07 & 会議所附 & 町内屋敷/町外屋敷 \\
\hline \multirow[t]{8}{*}{ 芳町 } & 08 & 会議所附 & 町内屋敷/町外屋敷 \\
\hline & 09 & 古市傅兵衛 & 町内屋敷（向う側） \\
\hline & 10 & 佐竹甚兵衛 & 会所地のみ \\
\hline & 11 & 会議所附 & 町内屋敷/町外屋敷 \\
\hline & 12 & 佐野政方 & 会所地のみ \\
\hline & 13 & 黒川仰右衛門 & 会所地のみ \\
\hline & 14 & 青地四郎左衛 & 会所地のみ \\
\hline & 15 & 堀内善兵衛 & 会所地のみ \\
\hline
\end{tabular}

\section{会所地の地主と開発形態}

この時期の会所屋敷はどのような意図で所有されたのかを、表 4 を用いて論じることにする。「明治沽券図」にある対象地域の会所屋 敷は 110 ケ所、その内、地主不明の 4 ケ所を除いた 106 ケ所に対し て、所有形態を分析した結果が表 4 である。

表 4 明治 6 年会所屋敷の所有形態（「明治沽券図」および表 4 により作成） 区分 会所屋敷のみ 隣接屋敷 町外屋敷 町内・町外 合計 $\begin{array}{lccccc}\text { 明治沽券図 } & 43 & 38 & 12 & 13 & 106\end{array}$

$\begin{array}{lllll}\text { (明治 } 6 \text { 年 }) \quad(40.57 \%) & (35.85 \%) & (11.32 \%) & (12.26 \%)\end{array}$

表 3 によると地主が会所屋敷のみを所有している場合はある所に 集中しているのではなく、全体的に拡散していたことがわかる。3・ 1 ・1 で、寛保期について会所屋敷の夕を所有している場合は、当時 比較的安かった会所屋敷を用いて日本橋で商業を創めようとする意 図があったのではないかと考えた。一方、明治期には、既に新道も 主要道となり、会所屋敷も一般の町屋敷とほとんど異ならなかった と思われる。 $3 \cdot 2$ で再び検討するが、明治期の会所屋敷の沽券金を みると町屋敷とあまり変わりがない。以上のことから、明治期には、 会所屋敷を一筆を所有していても商売には問題なかったし、会所屋 
敷は段々普通の町屋敷と同じ扱いをしていたことが考えられる。

表 3 によると隣接する屋敷の地主が会所屋敷を所有する場合、会 所屋敷のみ所有している場合のように全般的に広がっているが、特 に日本橋通りの西側に偏っていることがわかる。つまり本銀町 $1 \cdot 2$ 丁目、本石町 $1 \cdot 2$ 丁目、本町 $1 \cdot 2$ 丁目、本両替町、駿河町、金吹 町、本革屋町、室町 3 丁目で、正方形街区の真ん中に閉じられてい た会所地が屋敷になるとき、新道が通さないまま開発された部分で ある。江戸期から隣接している周辺の屋敷がほとんどの会所屋敷を 所有していたため新道は明治期まで通されなかったのではないかと 考えられる。明治期の会所屋敷の地主を調べた前項で述べたように 大部分の会所屋敷は『松沢家』・『下村家』のような大店が所有して いた。このように大店は隣接している会所屋敷を店世や付帯施設等 で利用寸るために集積したのではないかと考えられる。

隣接はしていないが町内にある屋敷の地主が所有している場合の 特徴として挙げられることは、これらの例が通旅籠町および芳町に 集中していることである。前述の通り通旅籠町は町内の大店であっ た下村家が大部分を所有しており、実質的には隣接している屋敷の 地主が所有している例と同様と見なすことができる。また芳町の場 合は会議所附とあり、これは会議所附が所有している土地で、それ が芳町に集めていただけである。すなわち、町内にある屋敷の地主 が所有している場合は意味としては隣接している屋敷の所有と見な してもよいだろう。

最後に町外にある屋敷の地主が会所屋敷を所有する場合も「寛保 沽券図」と同じく、投資として土地経営をしようとしたかどうかと いう疑問が生まれる。「明治沽券図」は「寛保沽券図」より所有地数 は増え、最も沽券金が高い地域で現れることがわかる。これは会所 屋敷のみ所有している場合でも論じたが、明治期にいたっては会所 屋敷の評価が表町の町屋敷とあまり变わりがなく、投資の価值もよ り高くなったからではないかと考えられる。土地経営をした例とし て本石町 4 丁目をみると、32 番地会所屋敷の地主は三井次郎右衛で ある (表 3 )。三井次郎右衛は三井江戸本店を駿河町に構えていたの に本石町 4 丁目にある会所屋敷の土地を所有していたことが分かる。 三井次郎右衛が本拠地外にも土地を所有していたのは、投資として 土地経営をしていたのだと考えられる。

\section{3-1-3 18-19 世紀における会所地の変化}

これまで「寛保沽券図」、「明治沽券図」の分析から会所屋敷の地 主、およびその所有の意図を探ってきた。本項では、これら 129 年 の隔たりがある二つの時点の沽券図から、会所屋敷はどのように変 容するのか読み取っていきたい。前項でも言及したが「寛保沽券図」 は対象地域の全てを収録しているわけではないため、残っている部 分に限って考察する（図 1)。

\section{会所屋敷の地主}

「寛保沽券図」に「明治沽券図」を重祆てみと、合筆は行ってい るが町割の線は同じであることに気づく。合筆されたものは「寛保 沽券図」の時点で地主が同じだった場合に限って行われていること も注目に值する。

「寛保沽券図」「明治沽券図」の二つの時点の沽券図で地主はどう 変わったのか。129年間変わらず同じ地主である屋敷は表 5 である。 129 年を隔てて地主名が同じであることは、大店の場合、襲名とい って当主の名を引き継いだものである。表 5 によると会所屋敷にも
こうした例が 3 件見られる。少数ではあるが会所屋敷にも寛保期か ら変わりなく大店が占有した例があったことがわかる。表 5 によれ ば「寛保沽券図」には名字が記されていないが、「明治沽券図」には 名字が記されている場合が多い。また、大伝馬塩町の 4 番などは、「寛 保沽券図」では「三郎助」が後見だったものが「明治沽券図」にな ると地主になっている。大伝馬町 1 丁目では他の町に比べて地主の 変化が少なく、彼らが土地を維持していたことがわかる。それは江 戸期から木綿問屋で有名な小津家、西村家、また三井家などの大店 が所有していたためであろう。

\begin{tabular}{|c|c|c|c|c|}
\hline 町名 & 地番 & 屋敷形態 & 「寛保沽券図」の地主 & 「明治沽券図」の地主 \\
\hline \multirow{2}{*}{ 大伝馬塩町 } & 03 & 町屋敷 & 七左衛門 & 久須木七左衛門 \\
\hline & 04 & 町屋敷 & 三郎助後見 寿蔵 & 三井三郎助 \\
\hline \multirow{2}{*}{ 鐵砲町 } & 14 & 町屋敷 & 石川庄兵衛 & 石川庄兵衛 \\
\hline & 26 & 会所屋敷 & 小林勘平 & 小林勘平 \\
\hline \multirow{8}{*}{ 大伝馬町 1 丁 } & 01 & 町屋敷 & 清左衛門 & 小津清左衛門 \\
\hline & 02 & 町屋敷 & 清左衛門 & 小津清左衛門 \\
\hline & 15 & 町屋敷 & 九郎左衛門 & 長井九郎左衛門 \\
\hline & 21 & 町屋敷 & 七左衛門 & 久須木七左衛門 \\
\hline & 25 & 町屋敷 & 次郎右衛門 & 三井次郎右衛門 \\
\hline & 26 & 町屋敷 & 三郎右衛門 & 西村三郎右衛門 \\
\hline & 27 & 町屋敷 & 三郎右衛門 & 西村三郎右衛門 \\
\hline & 28 & 会所屋敷 & 三郎右衛門 & 西村三郎右衛門 \\
\hline \multirow{2}{*}{ 大伝馬町 2 丁 } & 28 & 町屋敷 & 馬込勘解由 & 馬込彦一郎 \\
\hline & 29 & 町屋敷 & 馬込勘解由 & 馬込彦一郎 \\
\hline \multirow{2}{*}{ 通油町 } & 08 & 町屋敷 & 喜兵衛 & 上山喜兵衛 \\
\hline & 17 & 町屋敷 & 吉右衛門 & 坂江吉右衛門 \\
\hline 堀留町 2 丁目 & 11 & 町屋敷 & 次郎兵衛 & 長谷川次郎兵衛 \\
\hline \multirow{2}{*}{ 田所町 } & 09 & 町屋敷 & 大村彦太郎 & 大村彦太郎 \\
\hline & 10 & 町屋敷 & 小野善助 & 小野善助 \\
\hline 堀留町 3 丁目 & 05 & 町屋敷 & 勢州住宅次郎兵衛 & 長谷川次郎兵衛 \\
\hline \multirow{2}{*}{ 新乗物町 } & 02 & 町屋敷 & 伊勢屋甚十郎 & 松田甚十郎 \\
\hline & 11 & 町屋敷 & 小出三右衛門 & 小出三右衛門 \\
\hline \multirow{3}{*}{ 長谷川町 } & 11 & 町屋敷 & 石川庄兵衛 & 石川庄兵衛 \\
\hline & 12 & 町屋敷 & 石川庄兵衛 & 石川庄兵衛 \\
\hline & 16 & 町屋敷 & 田原屋庄左衛門 & 村越庄左衛門 \\
\hline 高砂町 & 07 & 町屋敷 & 次郎右衛門 & 三井次郎右衛門 \\
\hline 新和泉町 & 06 & 町屋敷 & 元之助 & 三井元之助 \\
\hline 芳町 & 04 & 会所屋敷 & 高橋寿貞 & 高橋利冶 \\
\hline \multirow{2}{*}{ 小舟町 2 丁目 } & 06 & 町屋敷 & 次郎右衛門 & 三井次郎右衛門 \\
\hline & 09 & 町屋敷 & 次郎右衛門 & 三井次郎右衛門 \\
\hline \multirow{2}{*}{ 小舟町 3 丁目 } & 08 & $\begin{array}{l}\text { 町屋敷 } \\
\end{array}$ & 庄左衛門 & 寺田庄左衛門 \\
\hline & 10 & 町屋敷 & 彦兵衛 & 川浪彦兵衛 \\
\hline 堀江町 1 丁目 & 03 & 町屋敷 & 清水八兵衛 & 清水市部兵衛 \\
\hline
\end{tabular}

\section{3-2 会所地とその周辺の沽券金}

会所屋敷の沽券金は、「寛保沽券図」および「明治沽券図」でどの ように表れるのか。その変化は見られるのか。

\section{「寛保沽券図」からみる沽券金}

まず、「寛保沽券図」における全般的な沽券金について考察してみよう。 「寛保沽券図」が全部残っているわけではないため、対象地域の全体的な分 析はできないが、本町通りから浅草まて繋ぐ大伝馬町通りが最も高かった 事がわかる。それから、水運が何よりも重要だった初期江戸であるため、 小舟町・堀江町・新材木町など水路に面している部分の沽券金も高かった のである。また、各町の角屋敷が著しく沽券金が高いのである。特徽的な のは、町別に角屋敷・主要道路に面している屋敷・横町屋敷・会所屋敷の 四段階に分けられ、沽券金が決められていたことである(図5)。 


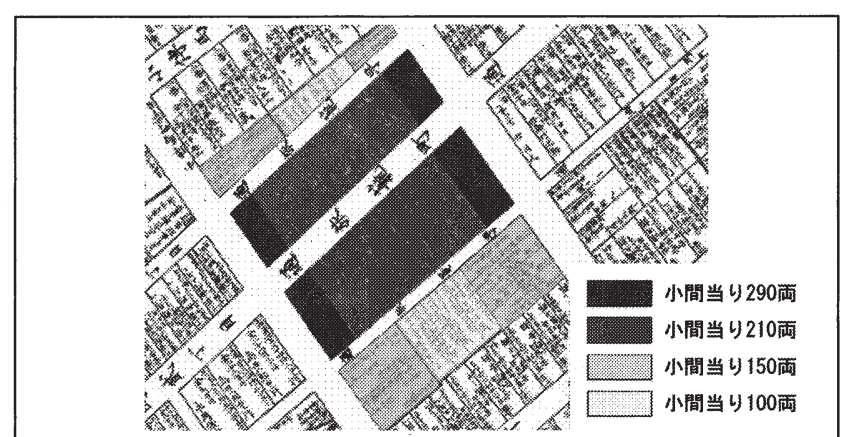

図5 通旅籠町の小間当たり沽券金（「寛保沽券図」により作成）

例えば、通旅籠町の小間当たりの沽券金 ${ }^{13}$ 調べると、角屋敷は 290 両、主要道路に面している屋敷は 210 両、横町屋敷は 150 両、最後 に会所屋敷は 100 両になる（表 6)。「寛保沽券図」に記載されてい る沽券金は現在の公示価格のことで、その価格は実際の売買価格で はなく、実例や周辺の沽券金高を参考にして作られたものである。 町別の基準は異なったが、一つの町の中ではその位置からある程度、 沽券金が定められていたと考えられる。

\section{「明治沽券図」からみる沽券金}

「明治沽券図」も「寛保沽券図」と変わらず、本町通りから浅草ま で繫ぐ大伝馬町通り、小舟町・堀江町・新材木町など水路に面して いる部分、また角屋敷の沽券金が高い。しかし、「寛保沽券図」より は、その沽券金の差がさほど高くない。また、屋敷の位置により、 小間当たりの沽券金が一定に決められていたのではなく、会所屋敷 も角屋敷のように高いところもあったことが注目される。

\section{会所屋敷の沽券金}

「寛保沽券図」から「明治沽券図」により、会所屋敷の沽券金を比 べるため、通旅籠町の小間当たりの沽券金を調べる。明治期に入っ てからは表間口よりは面積の方が重要になるため、小間当たりの沽 券金ではなく坪当たりの沽券金で分析することにする。

「寛保沽券図」に記載されている小間当たりの沽券金をみると、会 所屋敷は他の屋敷と比べると最大 $1 / 3$ に当たる 100 両である。しか し、「明治沽券図」によると、同じ会所屋敷であっても、通旅籠町 23 ・ 24 番地は角屋敷である 7 番地とは同じくらいで、他の角屋敷よ りははるかに高いことに注目される。また、会所屋敷である $25 ・ 26$ も平均坪当たり沽券金よりは高いことに気づく。すなわち、会所屋 敷は沽券地化された当時は沽券金が町の内で一番低かったが、それ が段々他の町屋敷と比べて同じか、または高いところもあるように 町屋敷として発展していったのである。

表 6 通旅籠町の沽券金（「明治沽券図」および「寛保沽券図」により作成）

\begin{tabular}{|c|c|c|c|c|c|c|c|}
\hline \multicolumn{4}{|c|}{ 地「寛保沽券図」 } & \multicolumn{2}{|l|}{ 「明治沽券図」 } & \multirow[b]{2}{*}{ 沽券金 } & \multirow[b]{2}{*}{ 坪当たり } \\
\hline 番 & 地主名 & 坪数 沽券金 & 小間当たり & 地主名 & 坪数 & & \\
\hline 3 & 五郎兵衛 & 144.61575 & 210 両 & 林留右衛門 & 169.812 & 1200 & 7.07 \\
\hline 6 & 3. $<$ & 146. 21575 & 210 両 & 下村源蔵 & 171.640 & 2200 & 12.82 \\
\hline 7 & 源助 & 245.13625 & 290 両 & 下村源蔵 & 287.760 & 3650 & 12.68 \\
\hline 8 & 善三郎 & 143. 01250 & 290 両 & 田島新之助 & 167.916 & 1300 & 7.74 \\
\hline 15 & 三郎右衛門 & $94.0 \quad 1450$ & 290 両 & 堀越源七 & 110. 319 & 1200 & 10.89 \\
\hline 23 & 藤左衛門 & 170.4500 & 100 両 & 下村源蔵 & 287.760 & 3650 & 12.68 \\
\hline 24 & 清助 & 110.0750 & 100 両 & 下村源蔵 & 171. 640 & 2200 & 12.82 \\
\hline 25 & 延寿院 & 159. 0200 & 100 両 & 下村正太郎 & 171.640 & 1300 & 7.57 \\
\hline 26 & 六左衛門 & 40.5516 & 100 両 & 林留右衛門 & 169. 881 & 1200 & 7.06 \\
\hline 28 & 八右衛門 & 185.21500 & 150 両 & 後藤長左衛門 & 234.722 & 1000 & 4.26 \\
\hline
\end{tabular}

\section{4. むすびにかえて}

会所地を囲む周辺の町屋敷が商業地として賑わっていた一方、こ うした賑わいから取残された会所地は誰がどのような意図で所有し たのか。

「寛保沽券図」により会所屋敷の所有者を調べた結果、会所屋敷の み所有している者と隣接する屋敷の地主が会所屋敷を所有している 者が多かった。一方、町外にある屋敷の地主が所有している例は少な かった。会所屋敷のみ所有する地主は、比較的安かった会所地におい て商売を始めようとする新規参入町人であったと思われる。また隣接 する屋敷の地主が会所屋敷を所有しているのは店舗を拡張するため であったと考えられる。最後に町外にある屋敷の地主が会所屋敷を所 有している例は、土地経営を行うために投資していたと推測できる。

一方、明治沽券図」では、会所屋敷の沽券金がはるかに高くなり、 地域によっては角屋敷より高いところもある。このことから、会所 屋敷のみ所有している場合でも、やがて充分な競争力を持つように なったことがわかる。それに従い、会所屋敷は大店による投資目的 で所有する場合が増えてきた。裏町であった会所屋敷が商業地とし て価值が上昇した理由の一つとして、大店の会所屋敷の所有が挙げ られる。「明治沽券図」によると、ほとんどの会所屋敷を大店が所有 していることがわかる。

会所地は共用地であった空地が町人の生活空間になるという大き な変容が起きていた。さらに、一大商業地であった日本橋において 会所地は町人により、非常に価值が高い町屋敷として発展していた。 道路に接していない街区の内部にある会所地を町屋敷として利用す るためには、アプローチを取るなど、近所との調整が必要となる。 このように江戸の会所地は個別の所有を越えた空間であった。

以上、会所地という江戸に特有な土地の変遷から、江戸の都市空 間は町人同士の相互調整によって推移し、そこには成熟した都市社 会の姿が見られる。

注

1）玉井哲雄『江戸、失われた都市空間を読む』（平凡社、1986 年）p. 121 2）先行研究では、双川喜文氏『近世の土地私有制』（技報堂、1980）、片倉比佐 子『江戸の土地問題』(同成社、2004)、岩淵令治『土地所有史』(山川出版社、 2002)、北島正元『土地制度史』(山川出版社、1974)、吉田伸之『近世都市社 会の身分構造』(東京大学出版会、1998) が挙げられる。

3）会所地のでき方と使い方について述べた、玉井哲雄氏の『江戸、失われた都市空 間を読む』(平凡社、1986) 研究、空地としての会所地の使い方、管理および禁令 についてふれた、伊藤好一氏の『江戸の町かど』（平凡社、1987）研究、「寛永江 戸図」をもとに、近世前期の江戸の会所地择領者について茨志麻氏の「近世前期 における江戸の会所地扯領者について」(『建築史学』23、1994) 研究がある。

4）東京史日本橋区役所『修新日本橋区史附録一寛保沽券図』（1937 年）

5）東京都中央区『中央区沿革図集一日本橋編』(東京都中央区立京橋図書館、1994)

6) 玉井哲雄『江戸、失われた都市空間を読む』（平凡社、1986 年）p. 23.

7) 安永 7 年 (1778) に江戸の町名主某が編纂した江戸の町触の集成であり、 天保 5 年 (1648) から宝暦 5 年 (1755) まで 108 年間に、町奉行から町年 寄を通じて実際に町方へ触出された約 3,100 通の触書を集めたものである。

8) 李佶勲「江戸会所地の沽券地化に関寸る研究」（日本建築学会計画系論文集 第 621 号、2007 年 11 月) pp. 237-242. 参照。

9）「明治沽券図」が「寛保沽券図」に比べて変わった点は以下のとおりである。 (1)町地の外に旧武家地も収録している沽券図であること。(2)町単位であっ た沽券図が小区ごとにまとめられでいること。(3)その小区の各町ごとに地 番がつけられていること。(4)公道に面した地所の間口寸法の記載がなくな ったこと。(5)地主だけで家主の名は記載されなくなったこと。

10）東京油問屋市場『東京油問屋史』(東京油問屋市場、2000 年)。

11）通旅籠町は、江戸初期からあり、「宽永江戸図」には「大伝馬目」と記されている。

12）株式会社大丸 『大丸二百五拾年史』（丸山、1967 年）

13）小間当たり沽券金とは、表間口の一間当たりの沽券金のことを示す。 